\title{
The Potential of Cellulosic Ethanol Production from Grasses in Thailand
}

\author{
Jinaporn Wongwatanapaiboon, ${ }^{1,2,3}$ Kunn Kangvansaichol, ${ }^{4}$ \\ Vorakan Burapatana, ${ }^{4}$ Ratanavalee Inochanon, ${ }^{4}$ Pakorn Winayanuwattikun, ${ }^{2,5}$ \\ Tikamporn Yongvanich, ${ }^{2,5}$ and Warawut Chulalaksananukul ${ }^{2,3}$ \\ ${ }^{1}$ Program in Biotechnology, Faculty of Science, Chulalongkorn University, Patumwan, Bangkok 10330, Thailand \\ ${ }^{2}$ Biofuels by Biocatalysts Research Unit, Chulalongkorn University, Patumwan, Bangkok 10330, Thailand \\ ${ }^{3}$ Department of Botany, Faculty of Science, Chulalongkorn University, Patumwan, Bangkok 10330, Thailand \\ ${ }^{4}$ PTT Research and Technology Institute, PTT Public Company Limited, Wangnoi, Ayutthaya 13170, Thailand \\ ${ }^{5}$ Department of Biochemistry, Faculty of Science, Chulalongkorn University, Patumwan, Bangkok 10330, Thailand
}

Correspondence should be addressed to Warawut Chulalaksananukul,warawut.c@chula.ac.th

Received 15 April 2012; Accepted 1 July 2012

Academic Editor: Anuj K. Chandel

Copyright (c) 2012 Jinaporn Wongwatanapaiboon et al. This is an open access article distributed under the Creative Commons Attribution License, which permits unrestricted use, distribution, and reproduction in any medium, provided the original work is properly cited.

\begin{abstract}
The grasses in Thailand were analyzed for the potentiality as the alternative energy crops for cellulosic ethanol production by biological process. The average percentage composition of cellulose, hemicellulose, and lignin in the samples of 18 types of grasses from various provinces was determined as 31.85-38.51, 31.13-42.61, and 3.10-5.64, respectively. The samples were initially pretreated with alkaline peroxide followed by enzymatic hydrolysis to investigate the enzymatic saccharification. The total reducing sugars in most grasses ranging from $500-600 \mathrm{mg} / \mathrm{g}$ grasses (70-80\% yield) were obtained. Subsequently, 11 types of grasses were selected as feedstocks for the ethanol production by simultaneous saccharification and cofermentation (SSCF). The enzymes, cellulase and xylanase, were utilized for hydrolysis and the yeasts, Saccharomyces cerevisiae and Pichia stipitis, were applied for cofermentation at $35^{\circ} \mathrm{C}$ for 7 days. From the results, the highest yield of ethanol, $1.14 \mathrm{~g} / \mathrm{L}$ or $0.14 \mathrm{~g} / \mathrm{g}$ substrate equivalent to $32.72 \%$ of the theoretical values was obtained from Sri Lanka ecotype vetiver grass. When the yields of dry matter were included in the calculations, Sri Lanka ecotype vetiver grass gave the yield of ethanol at 1,091.84 L/ha/year, whereas the leaves of dwarf napier grass showed the maximum yield of $2,720.55 \mathrm{~L} / \mathrm{ha} /$ year $(0.98 \mathrm{~g} / \mathrm{L}$ or $0.12 \mathrm{~g} / \mathrm{g}$ substrate equivalent to $30.60 \%$ of the theoretical values $)$.
\end{abstract}

\section{Introduction}

At present, the problem of global warming has been undeniably accepted worldwide. The cause of this situation is the increase of the greenhouse gases. The most important one is carbondioxide gas resulted from the combustion of fossil fuels and deforestation. One of the means to address this problem is the application of alternative energy. Thus, it is necessary to search for the sources of the renewable energy such as solar, wind, hydraulic, geothermal, and tide energy. On the other hand, the biofuels from biomass can also represent the promising type of energy source [1].
Bioethanol is now considered interesting biofuel and has been attracting attention since it can be directly used in place of benzene or diesel. It can be applied in the form of the mixture with benzene called gasohol or blended with diesel called diesohol. Bioethanol can be produced from biomass such as starch, sugar, and lignocellulosic materials. Previous studies revealed that the cheaper and suitable one for the production of ethanol can be derived from corncobs, grasses, wooden spills, and bagasses [2]. However, the use of starch and sugar from cassava, corn, and sugarcane which are basically human-food might possibly lead to the problem of food crisis. Therefore, lignocellulosic biomass 
which is abundant and low on production cost obtained from nonfood sources should be considered as an appropriate feedstock for ethanol production.

The energy crops are the types of plants expected to be cultivated as the raw materials for the production of the biofuels such as ethanol. Therefore, the plants with the fast growing rate such as grasses or shrubs should represent the appropriate energy crops for the future. These plants are perennial crops considered suitable as feedstock for lignocellulosic ethanol production because of high yields, low costs, fit for infertile land, and less environmental impacts [3]. Grasses are targeted as potential energy crops because of high productivity per hectare, abundancy, availability, and utilization of the whole plants. Fibres and storage carbohydrates within some species of grass can be used as substrates to produce ethanol whereas the species of grasses that contain high amounts of proteins can be used as nitrogenous waste for biorefineries [4].

Most of the researches in this area have been conducted on bioethanol production from either cellulose or hemicellulose hydrolysis to glucose or xylose for ethanol fermentation. In this research, both cellulose and hemicellulose from grasses were aimed to be used as the plant biomass as much as possible. The reason is from the fact that grasses contain very high percentages of total cellulose and hemicellulose. In general, the average compositions of grass biomass are $25-40 \%$ of cellulose, $25-50 \%$ of hemicellulose, and $10-30 \%$ of lignin $[2,5]$. The scientific researches on ethanol production from grasses have been mostly performed in switch grass $[6,7]$. Moreover, there were studies carried out in timothy grass, reed canary grass [8], Bermuda grass (Cynodon dactylon) [9], and silver grass (Miscanthus floridulus) [10], and so forth. These grasses are fast to grow likewise require less nutrient, thus suitable to be used as an energy crops for bioethanol production [1]. In particular, vetiver grass also has a potential for biofuel production by using a raw material in biomass power plant as well as ethanol production [11].

Ethanol production can be achieved from cellulose and hemicellulose hydrolysis to sugar by acid or enzyme catalysts. The use of acid is disadvantageous from the high temperature required, vigorous and nonspecific reactions resulting in the unwanted products. The containers have to be resistant to the acidic corrosion which is rather costly. Moreover, the process of waste elimination is needed for the remained acid contaminant. Therefore, the application of enzymes appears more interesting from the high specificity, neutral reaction without the unwanted by products, and therefore cost reduction in the waste management [12].

Obviously, the production of ethanol from agricultural wastes can only be applied for the short-term purpose since the amount of such waste won't be sufficient in the future. Therefore, in order to maintain long-term and successfully sustainable production of the alternative energy, the cultivation of energy crops together with the utilization of agricultural wastes and the search for the potential plants which can produce ethanol should be implemented. Grasses are considered one of the most suitable energy crops from their longevity, regeneration after the cutoff, and effective capability to withstand the drought. There are so many types of grasses that are popularly grown in Thailand. Hence, the objective of this research was to select the types of grasses in Thailand suitable as the feedstocks for cellulosic ethanol production by biological process. The fungus, Trichoderma reesei, has been widely accepted as the organism capable of producing the enzymes, cellulase, and hemicellulase in considerable quantities, appropriate for lignocellulosic biomass digestion [3]. Although the fermentation can be achieved from various processes, the application of simultaneous saccharification and cofermentation (SSCF) presents more advantages than the others. This method allows the raw materials to be hydrolyzed to hexose and pentose sugars for the subsequent fermentation to obtain ethanol in the single step. The obtained glucose gradually released from the hydrolysis will be continuously utilized in the fermentation. This low concentration of the glucose will result in the improved fermentation of xylose sugar [13]. Similarly, the yeasts, Saccharomyces cerevisiae and Pichia stipites, are widely known organisms that can utilize glucose and xylose for ethanol fermentation, respectively. Although, P. stipitis can ferment both glucose and xylose, but ethanol production rate from glucose is at least five times less than obtained with S. cerevisiae [14]. They were therefore applied in SSCF for higher efficient ethanol production.

\section{Materials and Methods}

2.1. Sampling and Raw Materials. 18 samples of grasses were collected from Chiang Mai, Lampang, Ratchaburi, and Petchburi provinces. All samples were dried at $60^{\circ} \mathrm{C}$ for 3 days, ground to small particles and later filtered through $0.4 \mathrm{~mm}$ mesh. Biomass contents were analyzed according to the method of Ruminant Nutrition Laboratory, University of Nebraska [15]. Neutral detergent fiber (NDF), acid detergent fiber (ADF), and permanganate lignin (PML) were determined. Hemicellulose content of biomass was determined as NDF minus ADF, lignin content of biomass as ADF minus PML, and cellulose content of biomass as PML minus residue after ash.

2.2. Enzyme Production. T. reesei TISTR 3081 (T. reesei QM9414) was obtained from Thailand Institute of Scientific and Technological Research (TISTR), Thailand and was later cultured in potato dextrose agar at $30^{\circ} \mathrm{C}$ for 8 days. A cork borer $(7 \mathrm{~mm}$ diameter) was used to cut agar plugs from a culture on PDA. Five agar plugs with the filaments of fungi were inoculated into $250 \mathrm{~mL}$ flask containing $100 \mathrm{~mL}$ of Mandels medium [16] for cellulase production in the presence of $10 \mathrm{~g} / \mathrm{L} \alpha$-cellulose as a carbon source. The induction of xylanase production was carried out in xylan medium containing $10 \mathrm{~g} / \mathrm{L}$ birchwood xylan as a carbon source, $5 \mathrm{~g} / \mathrm{L}$ corn steep liquor, $5 \mathrm{~g} / \mathrm{L}$ polypeptone, $1 \mathrm{~g} / \mathrm{L}$ yeast extract, $4 \mathrm{~g} / \mathrm{L} \mathrm{K}_{2} \mathrm{HPO}_{4}, 0.2 \mathrm{~g} / \mathrm{L} \mathrm{KCl}, 1 \mathrm{~g} / \mathrm{L} \mathrm{Mg}_{2} \mathrm{SO}_{4} \cdot 7 \mathrm{H}_{2} \mathrm{O}$, and $0.02 \mathrm{~g} / \mathrm{L} \mathrm{FeSO}_{4} \cdot 7 \mathrm{H}_{2} \mathrm{O}$. The media were sterilized by autoclaving at $121^{\circ} \mathrm{C}$ for $15 \mathrm{~min}$. After incubation at $30^{\circ} \mathrm{C}$ and shaken at $150 \mathrm{rpm}$ for 7 days, the mycelia were removed by filtration through Whatman no.1 filter paper. Crude enzyme was collected and determined for the activities of 
cellulase and xylanase using Whatman no.1 filter paper and $1 \%$ birchwood xylan as the substrates, respectively, according to Ghose [17].

One unit of enzyme was referred as the amount of enzyme which could convert substrates to $1 \mu$ mole of reducing sugar in 1 minute. Protein was determined by micro Lowry's assay [18] to obtain the specific activity of enzyme (U/mg protein).

2.3. Pretreatment. Alkaline peroxide pretreatment was performed. The milled grasses were suspended in $7.5 \%(\mathrm{v} / \mathrm{v})$ $\mathrm{H}_{2} \mathrm{O}_{2}$ and $\mathrm{NaOH}$ was then added to adjust the $\mathrm{pH}$ to 11.5 . The pretreated samples were then incubated at $35^{\circ} \mathrm{C}$, shaken at $250 \mathrm{rpm}$ for 24 hours. Finally, conc. $\mathrm{HCl}$ was added to adjust the $\mathrm{pH}$ to 4.8 before enzymatic hydrolysis [19]. The filtration was not required after the pretreatment. The liquid phase with solubilized hemicellulose and the solid phase with cellulose of the samples were subsequently hydrolyzed by the enzymes.

2.4. Enzymatic Hydrolysis. Cellulase (60 U/g substrate), xylanase (1200 U/g substrate), and $5 \mathrm{~mL}$ of $0.05 \mathrm{M}$ sodium citrate buffer $(\mathrm{pH} 4.8)$ were added to each substrate $(0.6 \mathrm{~g}$ of milled grass) and positive control (0.3 g of $\alpha$-cellulose mixed with $0.3 \mathrm{~g}$ of xylan). After the addition of the enzymes, the samples were incubated at $50^{\circ} \mathrm{C}$ and shaken at $150 \mathrm{rpm}$ for 72 hours. Total reducing sugar was analyzed by DNS method [20] and subsequently calculated for the percentages of conversion to cellulose and hemicellulose according to the equations below.

$\%$ conversion of cellulose and hemicellulose to sugars

$$
=\frac{\mathrm{B}}{\mathrm{A}} \times 100 \text {. }
$$

Total reducing sugar after the hydrolysis (ton/ha/year) was considered for selection of suitable grasses as the substrates for ethanol production by SSCF process.

$$
\text { Total reducing sugar after hydrolysis }=\frac{\mathrm{B} \times \mathrm{C}}{1000},
$$

where A is total cellulose and hemicellulose before hydrolysis ( $\mathrm{mg} / \mathrm{g}$ dry weight of substrate). B is total reducing sugar after hydrolysis ( $\mathrm{mg} / \mathrm{g}$ dry weight of substrate). C is dry matter yield of grass (ton/ha/year).

2.5. Fermentation. S. cerevisiae TISTR 5339 was obtained from TISTR, Thailand. P. stipitis CBS 5773 was obtained from The Centraalbureau voor Schimmelcultures (CBS), The Netherlands. Yeast strains were maintained at $4^{\circ} \mathrm{C}$ on YM agar containing $3 \mathrm{~g} / \mathrm{L}$ yeast extract, $3 \mathrm{~g} / \mathrm{L}$ malt extract, $5 \mathrm{~g} / \mathrm{L}$ peptone, $10 \mathrm{~g} / \mathrm{L}$ glucose, and $20 \mathrm{~g} / \mathrm{L}$ agar. S. cerevisiae and $P$. stipitis were precultured as inocula for fermentation in Erlenmeyer flasks containing $50 \mathrm{~mL}$ of $3 \mathrm{~g} / \mathrm{L}$ yeast extract, $3 \mathrm{~g} / \mathrm{L}$ malt extract, $5 \mathrm{~g} / \mathrm{L}\left(\mathrm{NH}_{4}\right)_{2} \mathrm{SO}_{4}$, and $20 \mathrm{~g} / \mathrm{L}$ glucose for S. cerevisiae or $20 \mathrm{~g} / \mathrm{L}$ xylose for P. stipitis [21]. The media were sterilized by autoclaving at $121^{\circ} \mathrm{C}$ for $15 \mathrm{~min}$. Flasks were incubated at $30^{\circ} \mathrm{C}$ and shaken at $150 \mathrm{rpm}$ for $9 \mathrm{~h}(S$. cerevisiae) and $10 \mathrm{~h}$ (P. stipitis).

$1.2 \mathrm{~g}$ of pretreated substrates was supplemented in fermentation medium containing $0.45 \mathrm{~g}$ yeast extract, $0.45 \mathrm{~g}$ malt extract, and $0.75 \mathrm{~g}\left(\mathrm{NH}_{4}\right)_{2} \mathrm{SO}_{4}$ in $7.5 \mathrm{~mL}$ of $0.05 \mathrm{M}$ sodium citrate buffer ( $\mathrm{pH}$ 5.0) and sterilized by autoclaving at $121^{\circ} \mathrm{C}$ for $15 \mathrm{~min}$. Cellulase and xylanase were filtered and sterilized through a $0.2 \mu \mathrm{m}$ filters and the enzymes were added with the activities of $72 \mathrm{U}$ and $1,440 \mathrm{U}$ in each flask, respectively. Then, $7.5 \mathrm{~mL}(5 \% \mathrm{v} / \mathrm{v})$ of each yeast strain was added last. Final volume was adjusted to $150 \mathrm{~mL}$ by sterilized distilled $\mathrm{H}_{2} \mathrm{O}$. The samples were incubated with shaking at $35^{\circ} \mathrm{C}, 150 \mathrm{rpm}$ for 7 days, and ethanol production was determined by gas chromatography (Shimadzu, Japan)

2.6. Statistical Analysis. Collected data (3 replicates) were analyzed by one-way ANOVA at 95\% confidence level. Comparison was performed by Duncan's Multiple Range Test (DMRT) using SPSS for Window version 15.0.

\section{Results and Discussion}

3.1. Raw Materials. The samples of 18 types of grasses were divided into 2 groups. The first group was composed of 8 types of the forage grasses (napier leaves, dwarf napier leaves, king napier leaves, bana leaves, purple guinea, ruzi, pangola, and atratum) and the second one contained 10 ecotypes of vetiver grasses (Kamphaeng Phet 2, Songkhla 3, Surat Thani, Sri Lanka, Roi Et, Loei, Nakhon Sawan, Prachuap Khiri Khan, Ratchaburi, and Kamphaeng Phet 1) as shown in Figure 1. Since the height of all the grasses in this study is more than 1 metre, and the harvest can be carried out several times per year, considerably huge amount of dry biomass can be obtained from the conversion. Both leaves and stems from the purple guinea grass, ruzi grass, pangola grass, atratum grass, and vetiver grasses were used since their stems are rather small. However, only the leaves were employed from napier grass, dwarf napier grass, king napier grass, and bana grass from their strong, hard stems together with the limitation of the specific types of facilities required for the chopping and grinding. As the compositions of biomass in each type of grass diverse immensely, even the same type possibly differs depending on the environment or the plant ages. The factors that can affect growth, production and composition of grasses can be genetics, soil properties, maintenance, amount, and distribution of rain. Moreover, the cuttings of the stems and leaves of plants for various purposes result in the decrease of photosynthetic activities thereby reducing the accumulation of carbohydrates [22]. On the contrary, the proteins will be increased [23].

From the analysis of the composition of the biomass in 18 types of grasses studied, it was found that all types contained the average quantities of cellulose in the range of $31.85-38.51 \%, 31.13-42.61 \%$ of hemicellulose and $3.10-5.64 \%$ of lignin (Table 1). The low level of lignin present in the samples of grasses used in this study appeared more advantageous than the other types, for example, $6.4 \%$ in coastal Bermuda grass, $12 \%$ in switch grass, $7.3 \%$ in $\mathrm{S} 32$ 
TABLE 1: Biomass composition of grasses.

\begin{tabular}{|c|c|c|c|c|c|c|}
\hline \multirow{2}{*}{ Grasses } & \multirow{2}{*}{ Dry matter yield (ton/ha/year) } & \multicolumn{5}{|c|}{ Biomass composition (\%) } \\
\hline & & Cellulose & Hemicellulose & Lignin & Ash & Others \\
\hline \multicolumn{7}{|l|}{ Forage grasses } \\
\hline Napier & $7.7^{*}$ & $32.92 \pm 1.48$ & $36.46 \pm 1.19$ & $3.60 \pm 0.67$ & $0.33 \pm 0.14$ & $26.69 \pm 3.04$ \\
\hline Dwarf napier & $17.5^{*}$ & $35.64 \pm 0.21$ & $34.19 \pm 1.24$ & $3.66 \pm 0.20$ & $0.13 \pm 0.12$ & $26.38 \pm 1.38$ \\
\hline King napier & $7.7^{*}$ & $32.01 \pm 0.14$ & $31.13 \pm 0.57$ & $3.10 \pm 0.04$ & $1.65 \pm 0.04$ & $32.11 \pm 0.53$ \\
\hline Bana & $7.7^{*}$ & $33.93 \pm 2.27$ & $35.12 \pm 1.62$ & $3.55 \pm 0.34$ & $0.18 \pm 0.01$ & $27.21 \pm 3.71$ \\
\hline Purple guinea & 18.8 & $33.40 \pm 0.74$ & $31.26 \pm 1.91$ & $4.00 \pm 0.54$ & $0.61 \pm 0.08$ & $30.73 \pm 2.10$ \\
\hline Ruzi & 14.1 & $33.64 \pm 0.92$ & $34.01 \pm 0.81$ & $4.56 \pm 0.17$ & $0.27 \pm 0.12$ & $27.52 \pm 1.67$ \\
\hline Pangola & 37.5 & $33.07 \pm 0.70$ & $35.46 \pm 1.27$ & $4.47 \pm 0.61$ & $0.28 \pm 0.01$ & $26.72 \pm 1.60$ \\
\hline Atratum & 18.8 & $34.87 \pm 0.61$ & $32.60 \pm 0.53$ & $5.64 \pm 0.22$ & $0.31 \pm 0.14$ & $27.75 \pm 0.97$ \\
\hline \multicolumn{7}{|l|}{ Vetiver grasses } \\
\hline Kamphaeng Phet 2 & 6.0 & $35.54 \pm 0.38$ & $39.02 \pm 0.89$ & $4.36 \pm 0.78$ & $0.07 \pm 0.04$ & $19.72 \pm 0.61$ \\
\hline Songkhla 3 & 5.8 & $31.85 \pm 1.73$ & $37.87 \pm 1.59$ & $4.67 \pm 0.49$ & $0.26 \pm 0.16$ & $25.67 \pm 2.69$ \\
\hline Surat Thani & 5.5 & $33.97 \pm 1.16$ & $39.12 \pm 1.57$ & $3.67 \pm 0.70$ & $0.09 \pm 0.03$ & $22.16 \pm 0.74$ \\
\hline Sri Lanka & 6.4 & $37.54 \pm 0.45$ & $38.33 \pm 2.07$ & $3.99 \pm 0.31$ & $0.08 \pm 0.01$ & $20.38 \pm 2.81$ \\
\hline Roi Et & 3.5 & $34.04 \pm 0.27$ & $42.61 \pm 1.17$ & $4.83 \pm 0.24$ & $0.04 \pm 0.04$ & $19.32 \pm 0.88$ \\
\hline Loei & 4.9 & $34.42 \pm 0.99$ & $42.43 \pm 1.32$ & $5.09 \pm 0.56$ & $0.08 \pm 0.07$ & $18.23 \pm 0.98$ \\
\hline Nakhon Sawan & 4.2 & $32.67 \pm 1.31$ & $39.60 \pm 1.25$ & $4.96 \pm 1.18$ & $0.06 \pm 0.04$ & $22.57 \pm 0.94$ \\
\hline Prachuap Khiri Khan & 8.5 & $35.53 \pm 1.52$ & $38.87 \pm 0.09$ & $4.65 \pm 1.52$ & $0.19 \pm 0.11$ & $20.44 \pm 2.26$ \\
\hline Ratchaburi & 7.6 & $38.51 \pm 0.25$ & $39.21 \pm 0.70$ & $4.79 \pm 0.48$ & $0.05 \pm 0.01$ & $17.58 \pm 0.87$ \\
\hline Kamphaeng Phet 1 & 6.5 & $34.95 \pm 0.58$ & $39.67 \pm 0.18$ & $5.06 \pm 0.70$ & $0.12 \pm 0.10$ & $20.47 \pm 1.39$ \\
\hline
\end{tabular}

${ }^{*}$ The yields of napier grass, dwarf napier grass, king napier grass, and bana grass were the values of leaves only.

rye grass (seed setting), $4.7 \%$ in orchard grass $[2,5]$, and $10.7 \%$ in Miscanthus grass [24]. Moreover, since the free sugars were not detectable from the samples, the hydrolysis was necessary in order to obtain the sugar prior to the further fermentation process. The contents of plant biomass can be used to initially indicate the potentiality of grasses whether they are suitable for the application as the energy crops. All the studied 18 types of plants contained high contents of the total cellulose and hemicellulose of approximately $60-80 \%$. Therefore, the determination of cellulose and hemicellulose can be applied to quantify the theoretical production of ethanol.

3.2. Enzyme Production. The enzymes produced from the fungus T. reesei TISTR 3081 were assayed for the activities of cellulase using $\alpha$-cellulose and xylanase using xylan as the carbon sources, respectively. The results revealed that cellulase and xylanase showed the activities of $0.948 \pm 0.05$ and $92.13 \pm 6.86 \mathrm{U} / \mathrm{mL}$, respectively, whereas the obtained specific activities were $1.09 \pm 0.09$ and $65.32 \pm 1.59 / \mathrm{mg}$ protein, respectively.

The various strains of fungus, Trichoderma, especially $T$. reesei including the mutants, have been popularly applied from the high capacity of the cellulase production suitable for the hydrolysis [3]. The enzymes have been shown to be tolerant against many inhibitors and show stability at $50^{\circ} \mathrm{C}$ comparatively higher than other types of fungi [25]. The advantages of the application of $T$. reesei are the fungal capability to produce the mixture of cellulases containing activities of at least 2 types of cellobiohydrolases, 5 types of endoglucanases together with $\beta$-glucosidases. In addition, hemicellulases can also be produced which was reported by Zhang and Lynd [26]. The studies on the production of cellulases and hemicellulases from the fungus, T. reesei RUT C30 in the presence of $7.5 \mathrm{~g} / \mathrm{L}$ of Solka Floc as the carbon source were also conducted by Juhász et al. [27]. The results revealed that the obtained specific activities of cellulase and xylanase by the FPU assay were approximately 0.58 and $119 \mathrm{U} / \mathrm{mg}$ protein, respectively. It can be clearly seen that the fungus, $T$. reesei can produce both cellulases and hemicellulases. Hence, the organism appears suitable for the production of the hydrolytic enzymes for lignocellulosic material degradation. As a result, the number of the types of enzymes required for the process can be reduced thereby reducing the costs.

3.3. Enzymatic Hydrolysis. In this research, only the glucose and xylose produced from the hydrolysis of cellulose and xylan by cellulase and xylanase were studied, respectively, since the main composition of hemicellulose is generally xylan. The comparison of the efficiency for the hydrolysis of each type of grass was evaluated from the percentages of the conversion of the total reducing sugar since each type contained different quantities of cellulose and hemicellulose. The pretreatment of the raw materials was conducted to disaggregate lignocellulose into the various compositions, namely, cellulose, hemicellulose, and lignin [25]. The objective was to remove lignin, reduce cellulose crystallinity, increase the porosity of the raw materials resulting in cellulose accessibility to hydrolysis for conversion 


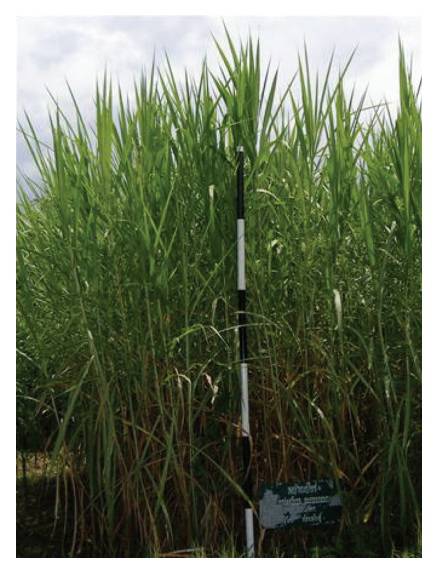

(a)

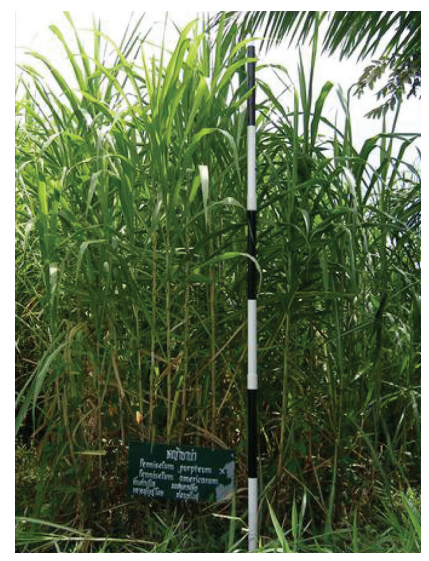

(d)

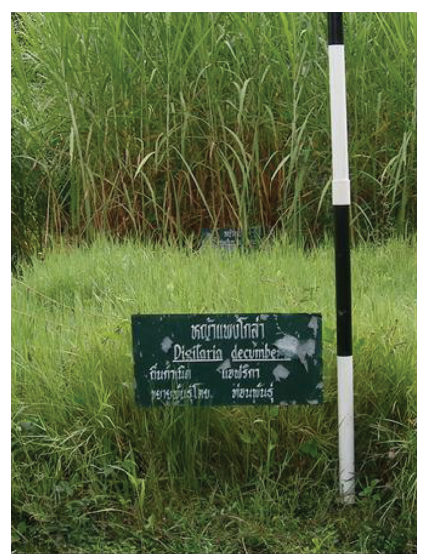

(g)

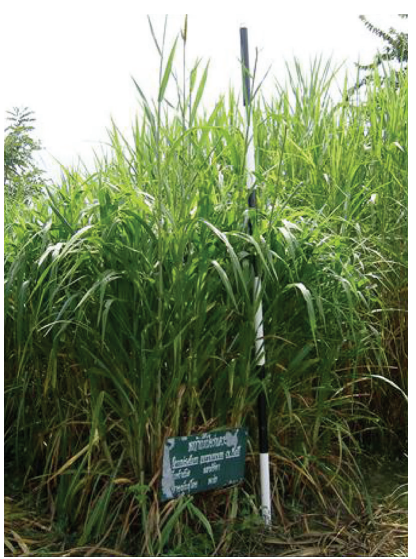

(b)

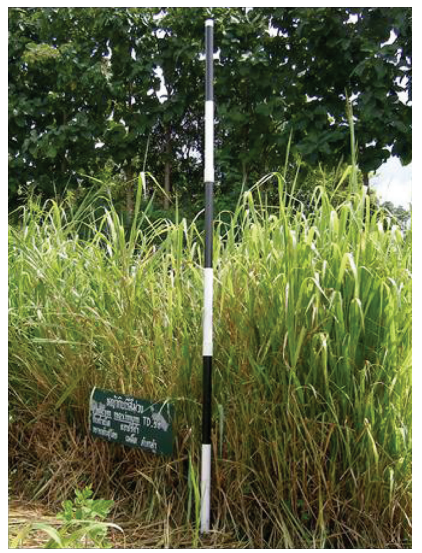

(e)

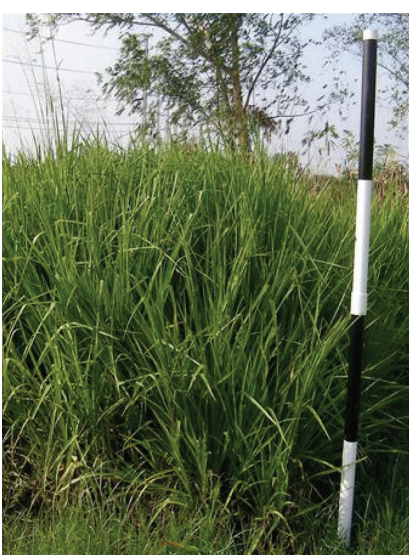

(h)

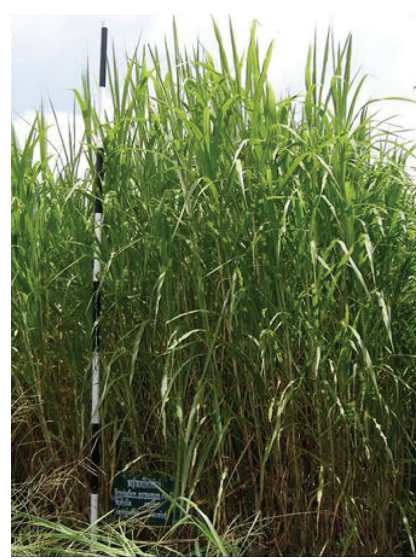

(c)

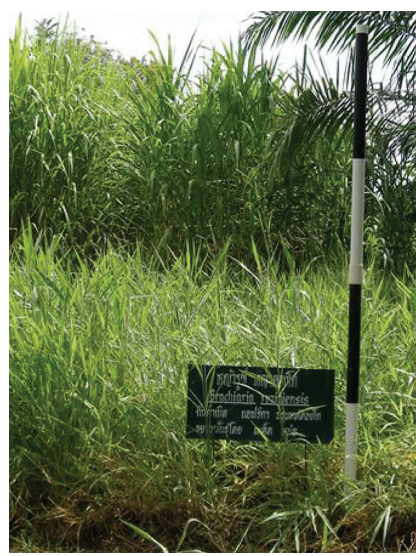

(f)

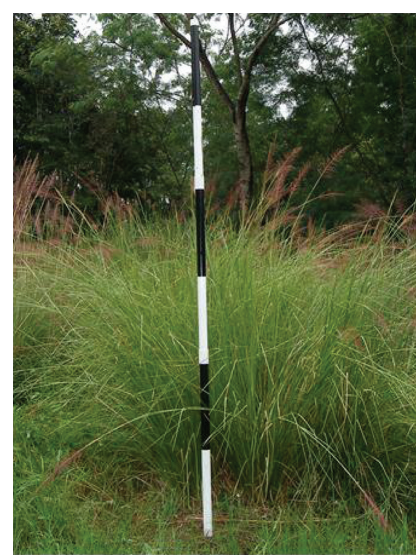

(i)

FIGURE 1: 18 samples of grasses collected from Chiang Mai, Lampang, Ratchaburi, and Petchburi provinces. Forage grasses (a-h), (a) napier grass (Pennisetum purpureum), (b) dwarf napier grass (P. purpureum cv. Mott), (c) king napier grass (P. purpureum cv. King Grass), (d) bana grass (P. purpureum $\times$ P. americanum), (e) purple guinea grass (Panicum maximum TD 58), (f) ruzi grass (Brachiaria ruziziensis), (g) pangola grass (Digitaria decumbens), (h) atratum grass (Paspalum atratum) and (i) vetiver grasses.

to fuels $[2,25,28]$. The use of alkaline hydrogen peroxide was an effective pretreatment of grass stovers and other plant materials in the context of animal nutrition and ethanol production. In addition, it has been widely applied with various substrates such as wheat straw [29, 30], rice hulls [19], sugarcane bagasse [31], barley straw [32], and
Miscanthus grass [24]. The advantages of this pretreatment are the use of reagents with low environmental impact and avoidance of special reaction chambers [33]. As a consequence, this pretreatment was selected for this research. From the preliminary results, no reducing sugars were obtained without the raw material pretreatment before the 
enzymatic hydrolysis (data not shown). Hence, the necessity of the pretreatment is very imperative.

From the hydrolysis of 18 types of grasses by chemical pretreatment with alkaline peroxide followed by hydrolysis with cellulase and xylanase produced from the fungus T. reesei TISTR 3081, the total reducing sugar obtained from the hydrolysis was tabulated in Table 2. Most of the grass samples' total reducing sugar showed the values in the range of $500-600 \mathrm{mg} / \mathrm{g}$ of raw materials equivalent to the concentration of $4-5 \mathrm{~g} / \mathrm{L}$ and the obtained conversion was approximately $70-80 \%$. There was no furfural and hydroxymethylfurfural produced from this method during the pretreatment [19]. These chemicals are always detected after the pretreatment and the hydrolysis by the use of acid and act as the inhibitors for the growth of yeasts used for the ethanol fermentation [34]. Rice hulls and wheat straw pretreated with alkaline peroxide could be converted to fermentable sugars with an excellent yield (96-97\%) by enzymatic saccharification $[19,29]$. The values were high since the commercial enzymes, namely, Celluclast $1.5 \mathrm{~L}$ (cellulase), Novozyme 188 ( $\beta$-glucosidase), and Viscostar $150 \mathrm{~L}$ (xylanase) were applied in their work. These commercial enzymes must absolutely give much higher activities than the enzyme produced from the fungus $T$. reesei in our research. Moreover, the presence of $\beta$-glucosidase facilitated the hydrolysis of cellobiose to glucose resulting in the higher percentages of sugar conversion.

Since the sugar content and the value of sugar conversion from each grass obtained by the enzymatic hydrolysis were rather indifferent, the decisive selection of the suitable grass for the subsequent fermentation was not accurately possible. Therefore, the dry mass values of the grass samples were included in the calculations of the obtained reducing sugar contents from the enzymatic hydrolysis and the theoretical production of ethanol could be later calculated from the reducing sugar, assuming that the theoretical ethanol yield for fermenting is $0.511 \mathrm{~g}$ per $\mathrm{g}$ of hexose or pentose. From the results tabulated in Table 2, 11 types of grassses with the total reducing sugars over 3.9 ton/ha/year or the theoretical values for the ethanol production exceeding 2,550 L/ha/year were selected for the subsequent fermentation in descending order from the maximum, namely, pangola, purple guinea, dwarf napier leaves, atratum, ruzi, Prachuap Khiri Khan, Ratchaburi, bana leaves, napier leaves, king napier leaves and Sri Lanka, respectively.

3.4. Fermentation. Hydrolysis of the main composition, cellulose and hemicellulose, into glucose and xylose as the substrates of fermentation is necessarily required for the production of ethanol. In this research, the mixture of 2 types of yeasts was used, $S$. cerevisiae and $P$. stipites, since the former organism can use only glucose while the latter can catalyze both glucose and xylose as the substrates. Nonetheless, $P$. stipitis showed slower rate of fermentation than S. cerevisiae [35]. There are various methods to achieve the fermentation but SSCF has been shown to be more efficient than the others from the fact that the raw materials can be hydrolyzed to hexose and pentose for further ethanol fermentation in single step. The gradual release of glucose from the hydrolysis can be continuously used for the fermentation resulting in the low concentration of glucose which yields better fermentation for xylose [13].

When the initially selected 11 types of grasses were fermented by SSCF by the addition of 2 types of yeasts; $S$. cerevisiae and $P$. stipitis together with 2 enzymes produced from T. reesei TISTR 3081; cellulase and xylanase at $35^{\circ} \mathrm{C}$ for 7 days, the ethanol production from various raw materials was tabulated in Table 3. The highest yield of ethanol, $1.14 \mathrm{~g} / \mathrm{L}$ or $0.14 \mathrm{~g} / \mathrm{g}$ substrate equivalent to $32.72 \%$ of the theoretical values, was obtained from Sri Lanka ecotype vetiver grass. For purple guinea grass and pangola grass, it was found that the lowest yield of ethanol was obtained at 6.08 and $6.8 \%$, respectively, compared to the theoretical values. This result conflicted with the preliminary results of enzymatic hydrolysis that purple guinea grass and pangola grass gave the highest conversion of sugar of $85.56 \pm 3.44$ and $76.03 \pm 0.84 \%$ respectively. This indicated that these 2 types of grasses may contain certain chemicals such as tannin or silica in the quantities that could possibly affect the activities of the enzyme and the growth of the yeasts resulting in the reduction of the ethanol production obtained from fermentation. Moreover, the presence of other substances toxic to the microorganisms in the system, such as the derivatives of lignin which are the phenolic compounds, may reduce the efficiency of the fermentation [36]. Isci et al. [7] studied the SSF fermentation in switchgrass by aqueous ammonia pretreatment and found that lignin could be eliminated by $40-50 \%$. The yield of ethanol at $72 \%$ of the theoretical values was obtained from the application of the fermentation mixture between commercial cellulase (Spezyme CP) with the activity of $77 \mathrm{FPU} / \mathrm{mL}$ together with S. cerevisiae $\mathrm{D}_{5} \mathrm{~A}$ for the period of 10 days. The differences could be from the fact that hemicellulose and lignin which can act as the inhibitors were preseparated. Only cellulose was used in the ethanol production by cellulase hydrolysis and single microorganism in SSF fermentation resulting in higher amount of ethanol.

In the analysis to determine the potential suitable grasses for the cultivation as the energy crops, the dry mass production of each type of grass (Table 1) was included in the calculation. The quantities of ethanol production were calculated in 3 cases as tabulated in Table 4 . For the first case, the theoretical ethanol production was calculated from the determination of cellulose and hemicellulose from each type of grass. The complete hydrolysis of cellulose and hemicellulose and the amount of sugar totally converted to ethanol were used for the calculations. The overall theoretical yield for conversion was $0.581 \mathrm{~g}$ of ethanol per $\mathrm{g}$ of xylan and $0.568 \mathrm{~g}$ of ethanol per $\mathrm{g}$ of cellulose, assuming that xylan represents the major sugar source in all the biomass hemicellulose. The theoretical ethanol yield for fermentation is $0.511 \mathrm{~g}$ per $\mathrm{g}$ of hexose or pentose [37]. The results showed that the highest yield of ethanol was obtained from the pangola grass at $18,706.69 \mathrm{~L} / \mathrm{ha} /$ year from the highest value of dry biomass at 37.5 ton/ha/year. As a result, it might have been suitable to be applied as the energy crops for the production of ethanol. Nevertheless, there are still 
TABLE 2: Total cellulose and hemicellulose of grasses before pretreatment and hydrolysis and total reducing sugar released after hydrolysis.

\begin{tabular}{|c|c|c|c|c|c|c|}
\hline \multirow[t]{2}{*}{ Grasses } & \multirow{2}{*}{$\begin{array}{l}\text { Total cellulose and } \\
\text { hemicellulose before } \\
\text { pretreatment and } \\
\text { hydrolysis } \\
\text { (mg/g substrate) }\end{array}$} & \multicolumn{2}{|c|}{ Total reducing sugar after hydrolysis } & \multirow[t]{2}{*}{$\begin{array}{c}\% \\
\text { conversion }\end{array}$} & \multirow{2}{*}{$\begin{array}{l}\text { Total reducing sugar } \\
\text { after hydrolysis } \\
\text { (ton/ha/year) }\end{array}$} & \multirow{2}{*}{$\begin{array}{l}\text { Theoretical } \\
\text { ethanol yield } \\
\text { (L/ha/year)* }^{*}\end{array}$} \\
\hline & & $\mathrm{mg} / \mathrm{g}$ substrate & $\mathrm{g} / \mathrm{L}$ & & & \\
\hline Napier & $693.76 \pm 26.67$ & $528.58 \pm 11.76$ & $4.14 \pm 0.34$ & $76.19 \pm 1.70$ & 4.05 & $2,621.06$ \\
\hline Dwarf napier & $698.37 \pm 10.78$ & $558.61 \pm 15.58$ & $4.13 \pm 0.34$ & $79.99 \pm 2.23$ & 9.78 & $6,331.31$ \\
\hline King napier & $631.40 \pm 4.91$ & $516.63 \pm 8.82$ & $4.04 \pm 0.32$ & $81.82 \pm 1.40$ & 3.96 & $2,561.81$ \\
\hline Bana & $690.54 \pm 36.65$ & $556.27 \pm 24.94$ & $4.36 \pm 0.46$ & $80.56 \pm 3.62$ & 4.26 & $2,758.31$ \\
\hline Purple guinea & $646.60 \pm 17.78$ & $553.20 \pm 22.22$ & $4.34 \pm 0.54$ & $85.56 \pm 3.44$ & 10.37 & $6,717.88$ \\
\hline Ruzi & $676.53 \pm 17.24$ & $469.13 \pm 19.09$ & $3.97 \pm 0.61$ & $69.34 \pm 2.82$ & 6.60 & $4,272.69$ \\
\hline Pangola & $685.30 \pm 19.62$ & $521.03 \pm 5.78$ & $4.09 \pm 0.39$ & $76.03 \pm 0.84$ & 19.54 & $12,654.31$ \\
\hline Atratum & $674.70 \pm 11.09$ & $505.93 \pm 27.58$ & $4.01 \pm 0.53$ & $74.99 \pm 4.09$ & 9.49 & $6,143.81$ \\
\hline Kamphaeng Phet 2 & $745.60 \pm 7.74$ & $586.55 \pm 22.59$ & $4.60 \pm 0.56$ & $78.67 \pm 3.03$ & 3.54 & $2,295.91$ \\
\hline Songkhla 3 & $697.13 \pm 29.98$ & $510.94 \pm 37.41$ & $3.98 \pm 0.20$ & $73.29 \pm 5.37$ & 2.97 & $1,921.38$ \\
\hline Surat Thani & $730.90 \pm 4.13$ & $563.81 \pm 18.02$ & $4.42 \pm 0.50$ & $77.14 \pm 2.47$ & 3.12 & $2,017.50$ \\
\hline Sri Lanka & $758.70 \pm 25.11$ & $619.31 \pm 6.38$ & $4.85 \pm 0.42$ & $81.63 \pm 0.84$ & 3.95 & $2,557.00$ \\
\hline Roi Et & $766.50 \pm 9.15$ & $516.95 \pm 16.35$ & $3.81 \pm 0.33$ & $67.44 \pm 2.13$ & 1.83 & $1,184.36$ \\
\hline Loei & $768.53 \pm 6.05$ & $550.89 \pm 22.62$ & $4.31 \pm 0.27$ & $71.68 \pm 2.94$ & 2.71 & $1,757.17$ \\
\hline Nakhon Sawan & $722.70 \pm 4.20$ & $532.25 \pm 17.80$ & $4.37 \pm 0.58$ & $73.64 \pm 2.46$ & 2.25 & $1,456.41$ \\
\hline Prachuap Khiri Khan & $744.05 \pm 14.42$ & $573.62 \pm 4.92$ & $4.31 \pm 0.19$ & $77.09 \pm 0.66$ & 4.85 & $3,139.24$ \\
\hline Ratchaburi & $777.20 \pm 4.50$ & $616.34 \pm 18.36$ & $4.54 \pm 0.25$ & $79.30 \pm 2.36$ & 4.68 & $3,033.76$ \\
\hline Kamphaeng Phet 1 & $746.17 \pm 7.01$ & $578.10 \pm 16.80$ & $4.52 \pm 0.28$ & $77.48 \pm 2.25$ & 3.73 & $2,414.94$ \\
\hline$\alpha$-cellulose + xylan & $1,000.00 \pm 0.00$ & $753.94 \pm 6.89$ & $8.76 \pm 0.06$ & $75.39 \pm 0.69$ & - & - \\
\hline
\end{tabular}

Grasses $(0.6 \mathrm{~g})$ were pretreated with alkaline peroxide $\left(7.5 \%(\mathrm{v} / \mathrm{v}) \mathrm{H}_{2} \mathrm{O}_{2} ; \mathrm{pH} 11.5 ; 35^{\circ} \mathrm{C}, 24 \mathrm{~h}\right)$ followed by enzymatic hydrolysis at $50^{\circ} \mathrm{C}$ for $72 \mathrm{~h}$. Positive control was $0.3 \mathrm{~g}$ of $\alpha$-cellulose mixed with $0.3 \mathrm{~g}$ of xylan.

* Theoretical ethanol yield (L/ha/year) was calculated from total reducing sugars after enzymatic hydrolysis, assuming that the theoretical ethanol yield for fermenting is $0.511 \mathrm{~g}$ per $\mathrm{g}$ of hexose or pentose.

TABLE 3: Ethanol production from grasses by SSCF process.

\begin{tabular}{|c|c|c|c|}
\hline \multirow{2}{*}{ Grasses } & \multicolumn{2}{|c|}{ Ethanol } & \multirow{2}{*}{$\%$ of the theoretical values } \\
\hline & $g / L$ & g/g substrate & \\
\hline Sri Lanka & $1.14 \pm 0.09^{\mathrm{a}}$ & $0.14 \pm 0.01^{\mathrm{a}}$ & $32.72 \pm 2.69^{a}$ \\
\hline Ratchaburi & $1.10 \pm 0.10^{\mathrm{a}}$ & $0.14 \pm 0.01^{\mathrm{a}}$ & $30.95 \pm 2.81^{\mathrm{a}, \mathrm{b}}$ \\
\hline$\alpha$-cellulose + xylan & $1.06 \pm 0.30^{\mathrm{a}, \mathrm{b}}$ & $0.13 \pm 0.04^{\mathrm{a}, \mathrm{b}}$ & $23.01 \pm 6.47^{b}$ \\
\hline Dwarf napier & $0.98 \pm 0.16^{\mathrm{a}, \mathrm{b}}$ & $0.12 \pm 0.02^{\mathrm{a}, \mathrm{b}}$ & $30.60 \pm 4.90^{\mathrm{a}, \mathrm{b}}$ \\
\hline Napier & $0.97 \pm 0.31^{\mathrm{a}, \mathrm{b}}$ & $0.12 \pm 0.04^{\mathrm{a}, \mathrm{b}}$ & $30.30 \pm 9.78^{\mathrm{a}, \mathrm{b}}$ \\
\hline Bana & $0.87 \pm 0.14^{\mathrm{a}, \mathrm{b}}$ & $0.11 \pm 0.02^{\mathrm{a}, \mathrm{b}}$ & $27.28 \pm 4.56^{\mathrm{a}, \mathrm{b}}$ \\
\hline Prachuap Khiri Khan & $0.80 \pm 0.12^{\mathrm{b}}$ & $0.10 \pm 0.01^{\mathrm{b}}$ & $23.31 \pm 3.48^{\mathrm{b}}$ \\
\hline King napier & $0.40 \pm 0.13^{c}$ & $0.05 \pm 0.02^{c}$ & $13.93 \pm 4.53^{c}$ \\
\hline Atratum & $0.36 \pm 0.05^{c}$ & $0.05 \pm 0.01^{\mathrm{c}}$ & $11.64 \pm 1.60^{c}$ \\
\hline Ruzi & $0.30 \pm 0.06^{c}$ & $0.04 \pm 0.01^{\mathrm{c}}$ & $9.56 \pm 1.79^{c}$ \\
\hline Pangola & $0.21 \pm 0.05^{c}$ & $0.03 \pm 0.01^{\mathrm{c}}$ & $6.80 \pm 1.58^{c}$ \\
\hline Purple guinea & $0.18 \pm 0.07^{c}$ & $0.02 \pm 0.01^{\mathrm{c}}$ & $6.08 \pm 2.49^{c}$ \\
\hline
\end{tabular}

Grasses $(1.2 \mathrm{~g})$ were pretreated with alkaline peroxide $\left(7.5 \%(\mathrm{v} / \mathrm{v}) \mathrm{H}_{2} \mathrm{O}_{2} ; \mathrm{pH} 11.5 ; 35^{\circ} \mathrm{C}, 24 \mathrm{~h}\right)$. SSCF process was performed using cellulase and xylanase $(72$ and $1440 \mathrm{U}$, resp.) from T. reesei for hydrolysis and S. cerevisiae and P. stipitis for cofermentation at $35^{\circ} \mathrm{C}$ for 7 days. Positive control was $0.6 \mathrm{~g}$ of $\alpha$-cellulose mixed with $0.6 \mathrm{~g}$ of xylan. Values not sharing a common superscript (a, b, c, and d) differ significantly (Duncan's Multiple Range Test). 
TABLE 4: Comparison of the theoretical ethanol yield and ethanol produced from SSCF process of 11 types of grasses.

\begin{tabular}{|c|c|c|c|c|c|c|}
\hline \multirow{3}{*}{$\begin{array}{l}\text { Rank } \\
1\end{array}$} & \multicolumn{4}{|c|}{ Theoretical ethanol yield (L/ha/year) } & & \\
\hline & \multicolumn{2}{|c|}{$\begin{array}{l}\text { Calculated from total cellulose and } \\
\text { hemicellulose }\end{array}$} & \multicolumn{2}{|c|}{$\begin{array}{l}\text { Calculated from total reducing } \\
\text { sugars after enzymatic hydrolysis }\end{array}$} & \multicolumn{2}{|c|}{ Ethanol yield from SSCF (L/ha/year) } \\
\hline & Pangola & $18,706.69$ & Pangola & $12,654.31$ & Dwarf napier & $2,720.56$ \\
\hline 2 & Atratum & $9,201.69$ & Purple guinea & $6,717.88$ & Ratchaburi & $1,330.06$ \\
\hline 3 & Dwarf napier & $8,889.88$ & Dwarf napier & $6,331.31$ & Pangola & $1,272.00$ \\
\hline 4 & Purple guinea & $8,818.50$ & Atratum & $6,143.81$ & Napier & $1,171.69$ \\
\hline 5 & Ruzi & $6,922.69$ & Ruzi & $4,272.69$ & Sri Lanka & $1,151.69$ \\
\hline 6 & Prachuap Khiri Khan & $4,576.81$ & Prachuap Khiri Khan & $3,139.25$ & Atratum & $1,071.19$ \\
\hline 7 & Ratchaburi & $4,297.88$ & Ratchaburi & $3,033.75$ & Prachuap Khiri Khan & $1,066.75$ \\
\hline 8 & Napier & $3,867.38$ & Bana & $2,758.31$ & Bana & $1,045.81$ \\
\hline 9 & Bana & $3,847.50$ & Napier & $2,621.06$ & Ruzi & 661.56 \\
\hline 10 & Sri Lanka & $3,519.81$ & King napier & $2,561.81$ & Purple guinea & 536.44 \\
\hline 11 & King napier & $3,517.00$ & Sri Lanka & $2,557.00$ & King napier & 489.81 \\
\hline
\end{tabular}

The theoretical ethanol yield for fermenting is $0.511 \mathrm{~g}$ per $\mathrm{g}$ of hexose or pentose.

many necessary factors required for the analysis such as the plantation areas for the cultivation, maintenance, and the composition in various grasses which may contain inhibitors affecting the activities of certain enzymes and the growth of the microorganisms in the fermentation process. Apparently, the obtained values of the sugar contents from the hydrolysis and the obtained ethanol from the fermentation were inconsistent with the theory. Hence, further studies on the hydrolysis of the biomass composition and the ethanol production should be conducted to determine the real quantity of the ethanol production. When the analysis has been performed in more details, other appropriate types of grasses may also have been discovered.

For the second case, when the theoretical values of ethanol production were calculated from the total reducing sugars obtained after the enzymatic hydrolysis, it was found that pangola grass still produced the highest theoretical values of ethanol production of 12,654.31 L/ha/yr despite the rather similar values of reducing sugars obtained from each type of grass after the enzymatic hydrolysis. Therefore, the highest yield of dry mass obtained from pangola grass consistently resulted in the highest value of theoretical ethanol production.

For the final third case, the ethanol production was calculated from the fermentation process, SSFC. It was found that dwarf napier grass leaves showed the highest yield of 2,720.56 L/ha/year. Therefore, this grass should have potential to be developed as the energy crop for the production of ethanol by this SSCF fermentation. Further studies can be carried out on the optimal conditions of fermentation to increase the production of ethanol approximately closed to the theoretical values. In this research, since the samples of rather aged grasses with the very strong and hard stems were collected, only the leaves were selectively applied for the experiments. Nevertheless, if the dwarf napier grass leaves were to be utilized for the application in the future, they should be harvested at the earlier stage so that both the stems and the leaves can be used.
When the theoretical ethanol production from pangola grass obtained from the second case was comparatively considered with the values obtained from the process of SSFC, it can be seen that the theoretical ethanol production from pangola grass was 5 -folds higher than what obtained from dwarf napier grass from the process of SSFC. On the contrary, the ethanol production from pangola grass obtained from SSFC was much lower than the theoretical values since the concentration of ethanol obtained was considerably low when compared with the others. This result suggested that the fermentation by the method in this study might not have been suitable for this grass. There might be some substances that inhibit the process of fermentation. Pangola grass may not be appropriate for the ethanol production by SSCF fermentation. However, pangola grass yielded the highest quantities of ethanol when the analysis was derived from both theoretical calculations. More importantly, it seems appropriately applicable as the hay from the tremendously high contents of dry mass in this grass. Hence, pangola grass may also present potentiality as the energy crop in Thailand. In case this type of grass would be further developed for the production of ethanol that would yield the closest values to the theory, the fermentation process should be further investigated with some alterations. In addition, the fermentation by SHF can represent the good alternative process since the high level of sugar can be produced from the enzymatic hydrolysis of this type of grass.

Recently, Bank of Thailand, in January 2012 reported the consumption of ethanol in Thailand at approximately 1.3 million litres per day or 457 million litres per year [38]. In case that the dwarf napier grass is to be applied for the production of ethanol by the process of SSFC, at least 0.17 million hectares of the plantation area are necessarily required. When the production of ethanol from other types of energy crops was comparatively studied, it has been found that the yield from sugar cane was equal to $4,900 \mathrm{~kg} / \mathrm{ha} /$ year or $6,210 \mathrm{~L} / \mathrm{ha} /$ year, whereas from cassava was $6,000 \mathrm{~kg} / \mathrm{ha} /$ year or $7,604 \mathrm{~L} / \mathrm{ha} /$ year [39]. Although the 
production of ethanol from the SSCF process derived from dwarf napier grass was found to be $2,720.56 \mathrm{~L} / \mathrm{ha}$ /year or 2.3 and 2.8-folds less than what obtained from the sugar cane and cassava, respectively, both of the mentioned energy crops are mostly utilized for human food consumption. Hence, the search for the alternative nonfood energy crops for the production of ethanol appears undeniably and continuously imperative in order to sustain the availability of the food energy crops for the prevention of food shortage problem in the future. This research particularly focused on the SSCF process that unfortunately had not been optimized. After the process, the total raw materials did not appear to be completely hydrolyzed. This might be from the fact that the optimal temperature for the activity of the enzymes should be in the range of $45-50^{\circ} \mathrm{C}$. However, the temperature applied in this process was at $35^{\circ} \mathrm{C}$. For the fermentation by yeast, the optimal temperature required has been known at $30^{\circ} \mathrm{C}$ [14]. Furthermore, the other conditions for the fermentation by these 2 microorganisms might not be optimal resulting in less ethanol production than it should have been. Therefore, the investigation on the optimal conditions about the various factors such as $\mathrm{pH}$, temperature, oxygen content, and the medium ingredients affecting the fermentation is considerably imperative. This will enhance the efficiency of the sugar cofermentation from both S. cerevisiae and P. stipitis. The method to produce high concentration of ethanol can be accomplished by producing the enzyme with high hydrolytic activities to increase the efficiency of the hydrolysis. Moreover, the obtained enzymes should exhibit high activities at low concentration. Since the enzyme applied in this research was totally isolated from the fungi in our lab, the activities were therefore considerably low compared to the commercials. As a consequence, the large quantities of the enzyme were necessarily applied for the process. This might be the reason why the obtained ethanol concentration was rather low. The improvement of the production media such as the sources of carbon and the growth conditions for the culture should greatly enhance the production of the enzyme with higher activities. In addition, the development of the better strain by genetic manipulation also represents the interesting method to increase the fungal capacity for the production of the better enzyme with higher activities. This can be achieved through the higher efficiency of the fermentation in various aspects, for example, the strains that can possibly use various types of sugars as the substrates, the capability of the organisms to tolerate the high temperature, and high concentration of ethanol. In particular, in case that cellulosic ethanol will be further produced for the industries in the future, the development of the strains with the capability of simultaneous hydrolysis and fermentation of lignocellulose should be more advantageous.

\section{Conclusions}

Lignocellulosic biomass, like grasses, could be successfully used in cellulosic ethanol production by biological process. Pangola grass has potential for saccharification before fermentation process, whereas dwarf napier grass has potential for fermentation by SSCF process. Therefore, they are potential alternative energy crops to serve as feedstocks for cellulosic ethanol production in the future for Thailand.

\section{Acknowledgments}

This study was supported by PTT Research and Technology Institute, PTT Public Company Limited, Thailand, and the Development and Promotion of Science and Technology Talents Project (DPST).

\section{References}

[1] C. A. Cardona, Ó. J. Sánchez, and L. F. Gutiérrez, Process Synthesis for Fuel Ethanol Production, CRC Press, Boca Raton, Fla, USA, 2010.

[2] Y. Sun and J. Cheng, "Hydrolysis of lignocellulosic materials for ethanol production: a review," Bioresource Technology, vol. 83, no. 1, pp. 1-11, 2002.

[3] M. Balat, H. Balat, and C. Öz, "Progress in bioethanol processing," Progress in Energy and Combustion Science, vol. 34, no. 5, pp. 551-573, 2008.

[4] B. E. Dale, M. S. Allen, M. Laser, and L. R. Lynd, "Protein feeds coproduction in biomass conversion to fuels and chemicals," Biofuels, Bioproducts and Biorefining, vol. 3, no. 2, pp. 219-230, 2009.

[5] R. L. Howard, E. Abotsi, E. L. J. Van Rensburg, and S. Howard, "Lignocellulose biotechnology: issues of bioconversion and enzyme production," African Journal of Biotechnology, vol. 2, no. 12, pp. 602-619, 2003.

[6] V. S. Chang, W. E. Kaar, B. Burr, and M. T. Holtzapple, "Simultaneous saccharification and fermentation of limetreated biomass," Biotechnology Letters, vol. 23, no. 16, pp. 1327-1333, 2001.

[7] A. Isci, J. N. Himmelsbach, A. L. Pometto III, D. R. Raman, and R. P. Anex, "Aqueous ammonia soaking of switchgrass followed by simultaneous saccharification and fermentation," Applied Biochemistry and Biotechnology, vol. 144, no. 1, pp. 6977, 2008.

[8] K. Belkacemi, G. Turcotte, P. Savoie, and E. Chornet, "Ethanol production from enzymatic hydrolyzates of cellulosic fines and hemicellulose-rich liquors derived from aqueous/steam fractionation of forages," Industrial and Engineering Chemistry Research, vol. 36, no. 11, pp. 4572-4580, 1997.

[9] Y. Sun and J. J. Cheng, "Dilute acid pretreatment of rye straw and bermudagrass for ethanol production," Bioresource Technology, vol. 96, no. 14, pp. 1599-1606, 2005.

[10] G. L. Guo, W. H. Chen, W. H. Chen, L. C. Men, and W. S. Hwang, "Characterization of dilute acid pretreatment of silvergrass for ethanol production," Bioresource Technology, vol. 99, no. 14, pp. 6046-6053, 2008.

[11] R. G. Grimshaw, "Vetiver System: A Green Investment For Sustainable Development," 2006, http:/www.vetiver.org/ ICV4pdfs/ICV4-PROG-IN.htm.

[12] C. E. Wyman, "Ethanol from lignocellulosic biomass: technology, economics, and opportunities," Bioresource Technology, vol. 50, no. 1, pp. 3-15, 1994.

[13] K. Öhgren, O. Bengtsson, M. F. Gorwa-Grauslund, M. Galbe, B. Hahn-Hägerdal, and G. Zacchi, "Simultaneous saccharification and co-fermentation of glucose and xylose in steampretreated corn stover at high fiber content with Saccharomyces 
cerevisiae TMB3400," Journal of Biotechnology, vol. 126, no. 4, pp. 488-498, 2006.

[14] P. Chandrakant and V. S. Bisaria, "Simultaneous bioconversion of cellulose and hemicellulose to ethanol," Critical Reviews in Biotechnology, vol. 18, no. 4, pp. 295-331, 1998.

[15] Ruminant Nutrition Laboratory, University of Nebraska, "Manual of Laboratory Techniques," 2009, http://feedlot.unl. edu/rnlab/ManualWebsite.htm.

[16] M. Mandels and J. Weber, "The production of cellulases," Advances in Chemistry Series, vol. 95, pp. 391-414, 1969.

[17] T. K. Ghose, "Measurement of cellulose activities," International Union of Pure and Applied Chemistry, vol. 59, no. 2, pp. 257-268, 1987.

[18] P. Held and J. Hurley, "Determination of total protein by the Lowry method using the BioTek instruments' ELx808 microplate reader," 2001, http://www.biotek.com/ resources/docs/ELx808_Determining_Total_Protein_Lowry_ Method.pdf.

[19] B. C. Saha and M. A. Cotta, "Enzymatic saccharification and fermentation of alkaline peroxide pretreated rice hulls to ethanol," Enzyme and Microbial Technology, vol. 41, no. 4, pp. 528-532, 2007.

[20] G. L. Miller, "Use of dinitrosalicylic acid reagent for determination of reducing sugar," Analytical Chemistry, vol. 31, no. 3, pp. 426-428, 1959.

[21] J. M. Laplace, J. P. Delgenes, R. Moletta, and J. M. Navarro, "Cofermentation of glucose and xylose to ethanol by a respiratory-deficient mutant of Saccharomyces cerevisiae cocultivated with a xylose-fermenting yeast," Journal of Fermentation and Bioengineering, vol. 75, no. 3, pp. 207-212, 1993.

[22] R. H. Brown and R. E. Blaser, "Relationships between reserve carbohydrate accumulation and growth rate in orchard grass and tall fescue," Crop Science, vol. 5, pp. 577-581, 1965.

[23] C. H. Middleton, "Dry matter and nitrogen changes in five tropical grasses as influenced by cutting height and frequency," Tropical Grassland, vol. 16, pp. 112-117, 1982.

[24] B. Wang, X. Wang, and H. Feng, "Deconstructing recalcitrant Miscanthus with alkaline peroxide and electrolyzed water," Bioresource Technology, vol. 101, no. 2, pp. 752-760, 2010.

[25] R. A. Silverstein, A comparison of chemical pretreatment methods for converting cotton stalks to ethanol [M.S. thesis], Biological and Agricultural Engineering, North Carolina State University, 2004.

[26] Y. H. Zhang and L. R. Lynd, "Toward an aggregated understanding of enzymatic hydrolysis of cellulose: noncomplexed cellulase systems," Biotechnology and Bioengineering, vol. 88, no. 7, pp. 797-824, 2004.

[27] T. Juhász, Z. Szengyel, K. Réczey, M. Siika-Aho, and L. Viikari, "Characterization of cellulases and hemicellulases produced by Trichoderma reesei on various carbon sources," Process Biochemistry, vol. 40, no. 11, pp. 3519-3525, 2005.

[28] P. Kumar, D. M. Barrett, M. J. Delwiche, and P. Stroeve, "Methods for pretreatment of lignocellulosic biomass for efficient hydrolysis and biofuel production," Industrial and Engineering Chemistry Research, vol. 48, no. 8, pp. 3713-3729, 2009.

[29] B. C. Saha and M. A. Cotta, "Ethanol production from alkaline peroxide pretreated enzymatically saccharified wheat straw," Biotechnology Progress, vol. 22, no. 2, pp. 449-453, 2006.

[30] B. Qi, X. Chen, F. Shen, Y. Su, and Y. Wan, "Optimization of enzymatic hydrolysis of wheat straw pretreated by alkaline peroxide using response surface methodology," Industrial and Engineering Chemistry Research, vol. 48, no. 15, pp. 7346-7353, 2009.
[31] S. C. Rabelo, R. M. Filho, and A. C. Costa, "A comparison between lime and alkaline hydrogen peroxide pretreatments of sugarcane bagasse for ethanol production," Applied Biochemistry and Biotechnology, vol. 148, no. 1-3, pp. 45-58, 2008.

[32] B. C. Saha and M. A. Cotta, "Comparison of pretreatment strategies for enzymatic saccharification and fermentation of barley straw to ethanol," New Biotechnology, vol. 27, no. 1, pp. 10-16, 2010.

[33] G. Banerjee, S. Car, J. S. Scott-Craig, D. B. Hodge, and J. D. Walton, "Alkaline peroxide pretreatment of corn stover: effects of biomass, peroxide, and enzyme loading and composition on yields of glucose and xylose," Biotechnology for Biofuels, vol. 4, article 16, 2011.

[34] R. Purwadi, "Continuous Ethanol production from diluteacid hydrolyzates: detoxification and fermentation strategy," Doctoral dissertation, Department of Chemical and Biological Engineering, Chalmers University of Technology, 2006.

[35] M. Taniguchi, T. Tohma, T. Itaya, and M. Fujii, "Ethanol production from a mixture of glucose and xylose by coculture of Pichia stipitis and a respiratory-deficient mutant of Saccharormyces cerevisiae," Journal of Fermentation and Bioengineering, vol. 83, no. 4, pp. 364-370, 1997.

[36] J. N. Nigam, "Ethanol production from wheat straw hemicellulose hydrolysate by Pichia stipitis," Journal of Biotechnology, vol. 87, no. 1, pp. 17-27, 2001.

[37] J. R. Hettenhaus, "Ethanol fermentation strains present and future requirements for biomass to ethanol commercialization," 1998, http://infohouse.p2ric.org/ref/38/37753.pdf.

[38] Bank of Thailand, "Report of ethanol price of Thailand," 2012, http://www.bot.or.th/Thai/EconomicConditions/Thai/ Northeast/commodities/Doclib_CommodityMonthly/ Ethanol\%20Monthly-01-55.pdf.

[39] M. Balat and H. Balat, "Recent trends in global production and utilization of bio-ethanol fuel," Applied Energy, vol. 86, no. 11, pp. 2273-2282, 2009. 

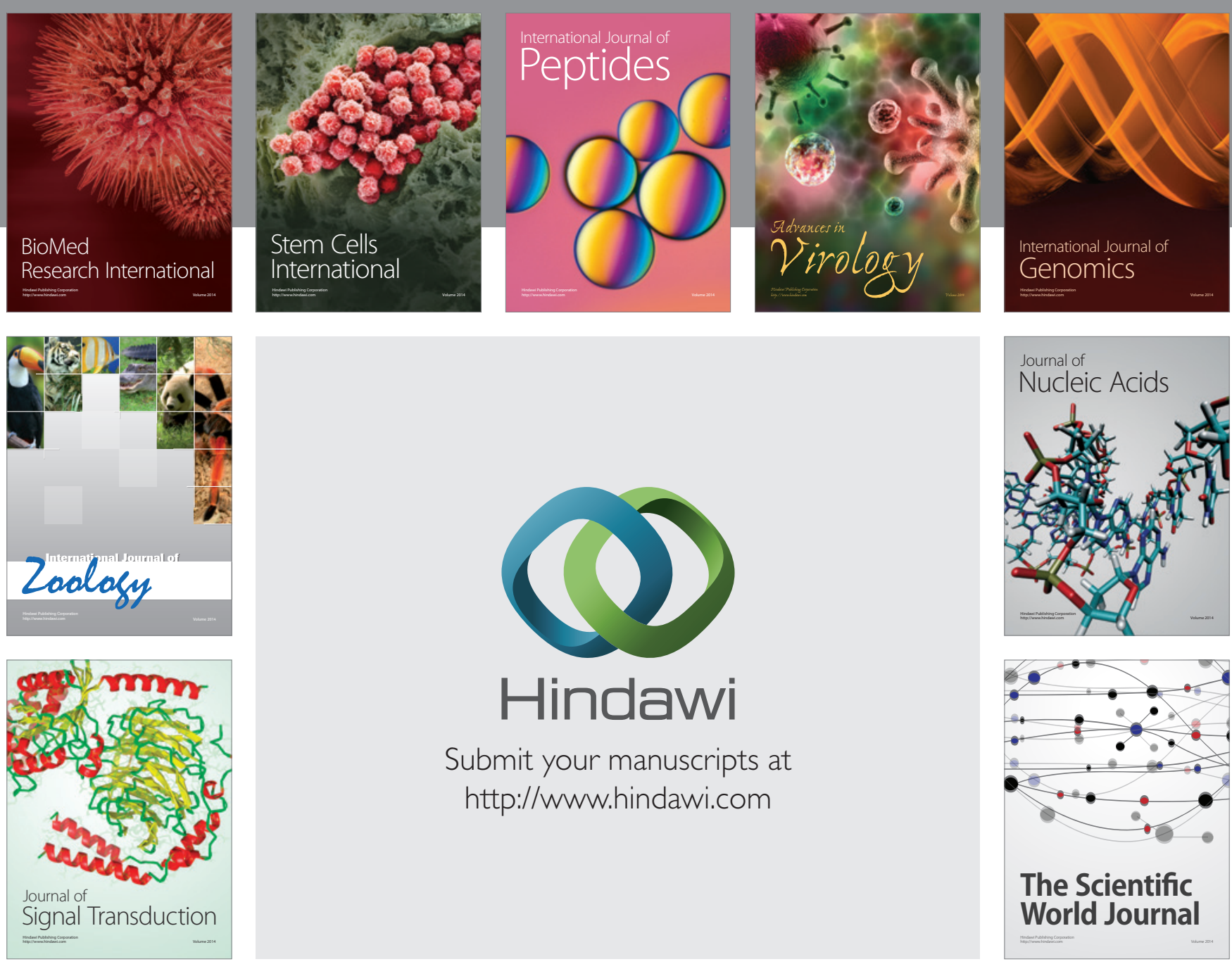

Submit your manuscripts at

http://www.hindawi.com
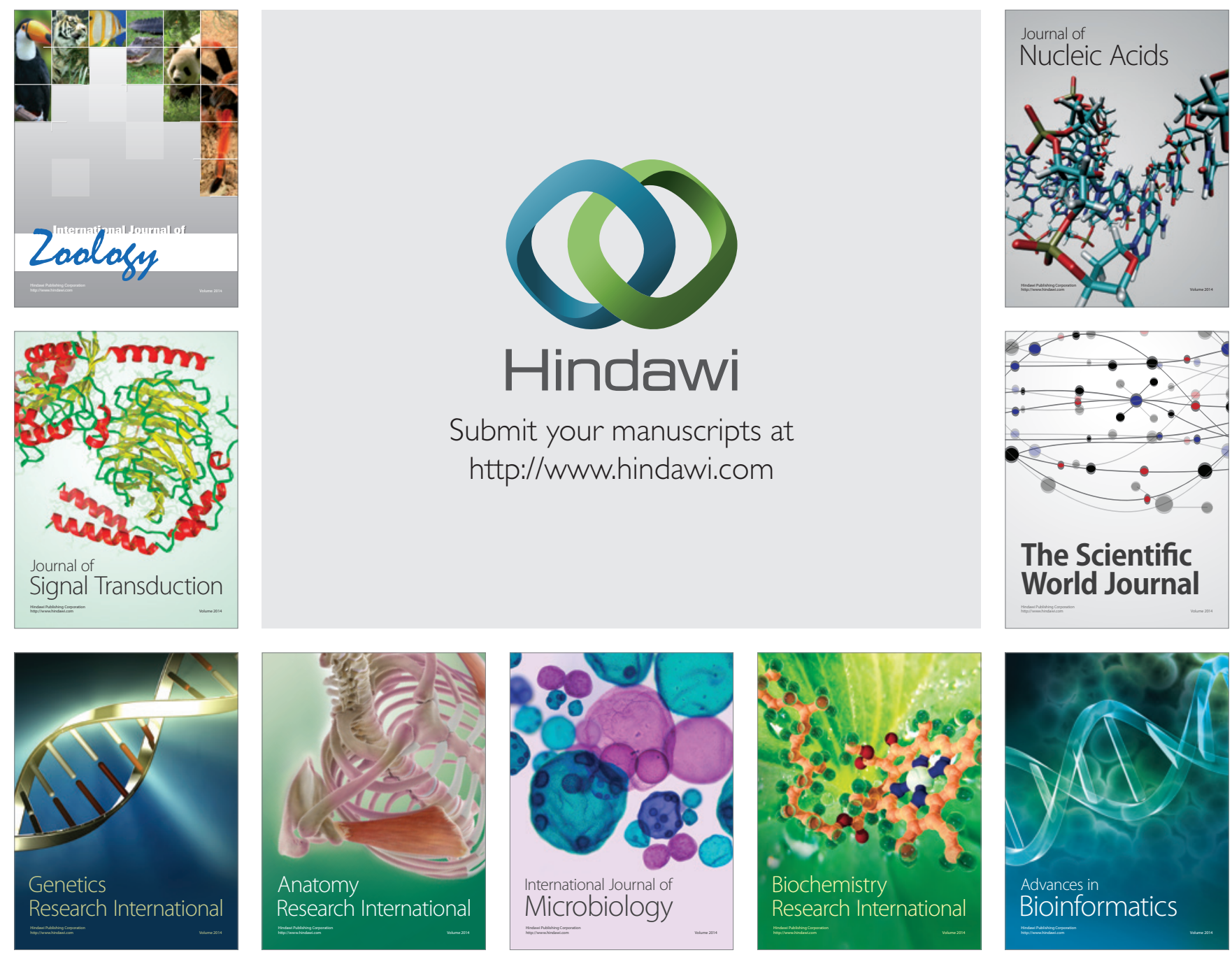

The Scientific World Journal
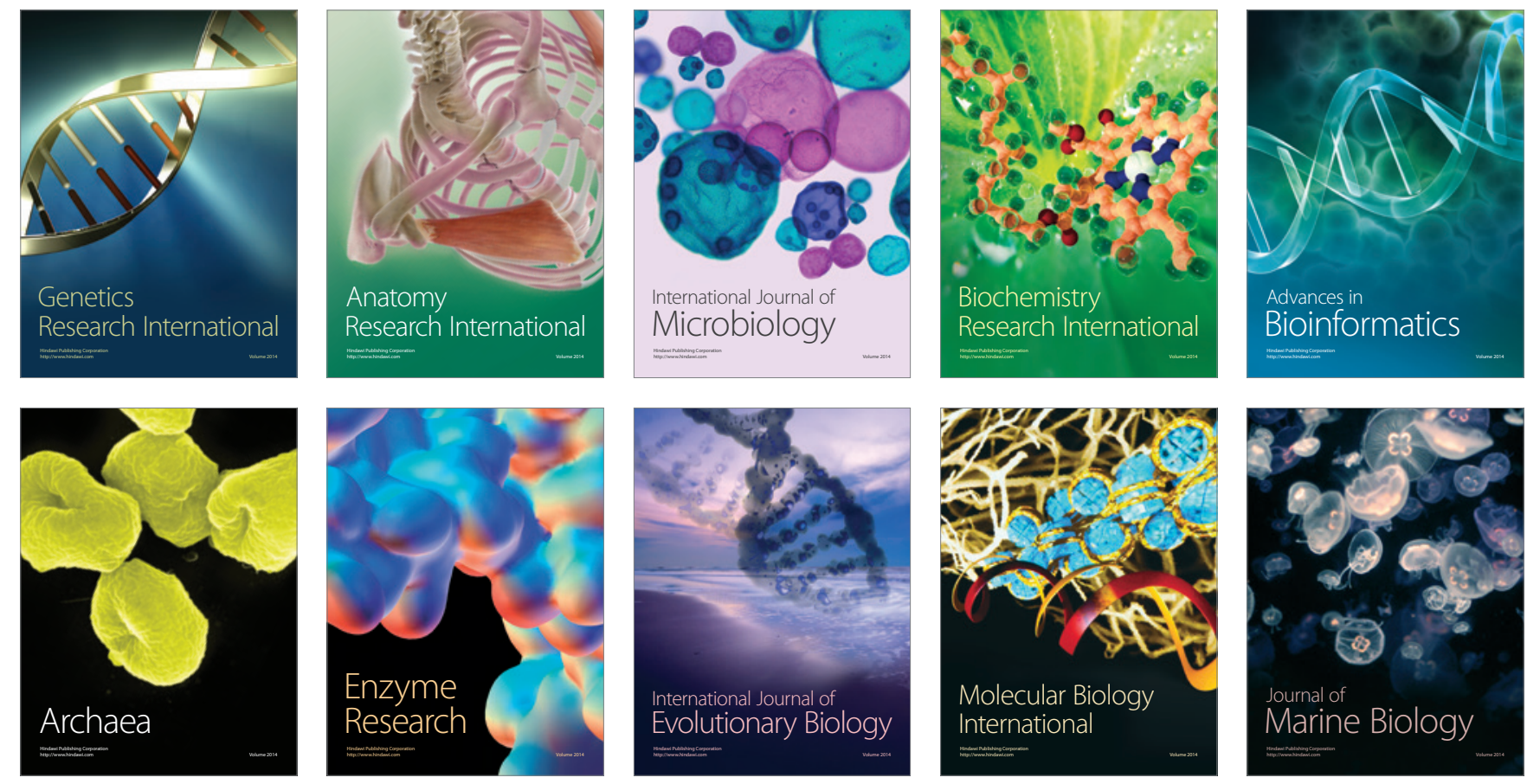